\title{
Loving the Young Adult Reader Even When You Want to Strangle Him (or Her)!
}

Adapted from the keynote speech delivered at the Arizona English Tachers' Association State Convention, October 16, 2004

$\mathbf{T}$ he title of my message, "Loving the Young Adult Reader Even When You Want to Strangle Him, (or Her)," is based on my belief that we need to quit whining about teenagers and begin to celebrate them instead. I'm officially on my soap box now, so as I stand at the podium up here on the stage, I want to warn those of you who are sitting in the first three rows that you are in the splash zone. If you have ever been to Sea World, then you know what happens when Shamu hits the water after a big jump, and you know what the term splash zone means. Well, when I really get into it, I start to spit and foam at the mouth. So, I'm sorry I didn't bring any of those clear plastic ponchos for you to put on over your clothes but you might want to put a mask on; I don't know, but we'll see. You might also want to get out a pen and a piece of paper. There are two writing prompts or exercises a little bit later that I want you to do. Not here, but when you get home.

I'm going to give you my background, briefly, to help explain why I wrote a couple of the books I wrote and the impact I have had on teenagers. This was all unanticipated by the way; I did not set out to write books for teenagers. I have been put in a unique position, as have many YA authors, of becoming a sort of mother/father confessors for this generation. When young people read a lot of books and actually connect with them, they often seek out the writer, through email, letters or in person, to talk to us in a uniquely intimate way. I want to share some of the feedback that I've received from my readers because I believe that you, as teachers, librarians and others who work with young adult readers, need to hear this.

Frankly, I hated school. I was the student that teachers often don't like to have because of the dilemma I presented; I was tall, so they wanted to put me in the back row, but in the back row I either got in lots of trouble or I ignored the teacher. No offense intended, nothing personal against my teachers, but it's just very hard for me to sit still for any long periods of time. I do some of my finest writing, by the way, at conferences. Those of you sitting in the back row, I suspect that you are all secret novelists and you've chose the back row so that once my voice begins to lull into a rhythm, like a white noise, then you can start working on my novels, your novels. Go ahead, you have my blessings. That's how I get some of my finest work done.

I left high school early to be a foreign exchange student in Denmark and missed my senior year in the states, but if you want to know what I really think about high school, just read Speak. That's what it pretty much felt like for me, particularly ninth grade. I made friends eventually so it wasn't all bad, and I'll give you the details of that in a moment. but leaving was a good thing, and when I came back to the states, I went to community college, which I loved. Community college was a godsend for me. And from commu- 
nity college, I transferred and went to Georgetown University, which was fun but it gave me a totally useless degree and a lot of debt (which I finally paid off). I studied historical linguistics, which, as I mentioned in an earlier session, qualifies me to work at the mall. But it was fun at the time.

I wound up working as a journalist for a couple of newspapers that had wonderful editors who taught me how to write (once they finished throwing dictionaries at my head). From that newspaper writing, I started to write for fun. At that point I had little kids around my house, so I began to write for children. I was not going

to write about or for

\section{Bad things are everywhere}

\section{I look: in my school, in my}

city, in my family, nothing

is happy, everything is

broken. How did your

character find the strength

\section{to go on?"}

teenagers; in fact, I didn't

even enjoy being a teen-

ager. You know how you

try to not think about those weird, awkward breakthrough years. I should tell you now that through a combination of my kids and my stepkids, we have girls, 19, 18 and 17 and a 12-year-old boy, so we're just up to our ears in adolescence.

A letter I received this year kind of summarizes what I've learned about teenagers in the last four or five years. I got this letter about six months ago from Slovenia (who knew my books were being read by teens in Slovenia?). It was written in English, very well written in English, from a young girl. I think she was sixteen, and she has relatives in northern California. While visiting in northern California, she had picked up a copy of Speak and taken it back to Slovenia. I have forgotten which city she lives in, but it is devastated, bombed out from all the wars those folks have had. Its economy is depressed, and so it is very similar to Eastern Europe in the 1950s and the 1960s. She wrote me a very sweet letter, continuing for several paragraphs before saying,

"I should probably get to my point. I read your book and I have a question for you. The main character in your book, Speak, was very sad because bad things had happened to her. That's how I feel all the time. Bad things are everywhere I look: in my school, in my city, in my family, nothing is happy, everything is broken. How did your character find the strength to go on?"

I can't get that letter out of my head. I think a lot of teenagers are asking this of us. They want us to show them how to find the strength to go on. They desperately want us to give them the tools they need to go on. These are very, very, difficult circumstances. I understand the sadness that girl was talking about because I spent a lot of time living in the middle of that.

I was blessed with an idyllic childhood prior to adolescence. My dad was a preacher, and after a couple of country churches, when I was in first grade, we moved to Syracuse University where my father became a chaplain at Syracuse University. It was awesome! College students were always in our house, and they were all like big brothers and big sisters to me. My dad was the big man on campus, my mom had a job she loved, and I could walk to school.

It was a childhood you would hope all of your kids have, but one which, of course, had to come crashing around me as soon as I reached adolescence. I changed schools in sixth grade, seventh grade and eighth grade for a variety of reasons, and my family really hit a difficult patch. My father had a falling out, a bloody falling out over a very significant issue with his church, and he left, which for my father was a recipe for spiritual suicide.

My parents spent probably the next five years going in and out of mental illness and very severe alcoholism. My sister and I were confused, to say the very least. We moved to a very expensive, preppy region of Syracuse. We lived in a crappy little apartment, and I was the poor kid at school when I walked into ninth grade, which also explains Speak. Of course, you know, all teenagers have to rebel against their parents, but when your dad is a minister sometimes, if you have my kind of personality, you feel compelled to rebel against God, too.

This is a really big thing, to rebel against God. It takes a lot of time. It takes a lot of energy. It was not fun. Lots of people have these types of issues in their lives, and I have to say we worked out any kind of pain we went through in my family. Both of my parents are still with us, and they're doing OK. We're all at peace, and I love them very, very much. There was one shining moment in eighth grade when I was supposed to be getting confirmed as a United Methodist kid. Of course, my dad couldn't do my confirmation; I had to go to another church for that. The night before my confirmation I went to my pastor and said, 
"OK, you want me to come tomorrow, you want me to say all this stuff, and join the church," and I said, "But how can I do that when you guys are treating my father this way?" For the first time I spoke up, and he didn't answer me. So, I chose not to be confirmed. When I eventually did join a church, I was a real little devil, so I became a Quaker. Chris Crutcher's autobiography is called King of the Mild Frontier, and I think mine might be called Born to Be Mild because that's kind of what I've become. I'm a bad Quaker. I'm a Quaker with evil tendencies. But I try really hard.

When I finally escaped, and I understand the need to escape, to get out of the house, I went to Denmark and worked on a pig farm rather than suffer through senior year in my high school back in the states. During all of those college years following that, I can honestly tell you I worked very hard actively trying not to think about my previous life as a teenager. I just couldn't do it. As I got married and had children and raised them up, I still wouldn't even consider reflecting back on those years. I guess maybe the reason the book is called Speak and I talk about Speak all the time is that the pain was actually $U N$-speakable until later in my life, and the title Speak is a meant to express irony. Young adults do experience a lot of pain, and often, perhaps, their behavior is an acting out caused by a hurt too deep for words.

Understanding this, what we need to do as teachers, librarians and others who work with young people is to love and honor them despite and BECAUSE of their weaknesses, as well as their strengths. As an adolescent you just have all that energy, and the wonder of having to deal with all that passion and a powerful sense of the possible.

It's a hazard of being an author that you tend to see metaphors everywhere. I see children as blank sheets of paper. I see teenagers as rough drafts. They're always adding details to fit these new personalities. They're putting in new information; they're expanding to fit their larger bodies and their larger sense of self. Then they cut, they contract, they pull back in when they run up against unexpected pain or harshness, they're always polishing these new versions of themselves, trying to see who will stay in control. Our culture is not equipped to love and cherish teenagers. We'll take their money, we're very happy to take their money, but we don't give them much back in return.
The letters that I get are heart-wrenching. There are the ones you might expect which come from survivors of sexual assault. I'm here to tell you right now, folks, there is a whole lot more of sexual assault going on in the middle schools and the high schools of America that even the experts aren't willing to admit. It's appalling. But they also write to me about harassment, about bullying, about feeling powerless and about feeling voiceless. I think the reason that Speak has been as powerful as it has been is not because of the whole rape thing. Speak is not really about rape. I have come to believe that Speak is a book about depression. Pretty much every kid in America has gotten to that ugly, gloomy, dark hole that they can't find a way out of. I've gotten letters that say, “Ok, like, I'm the biggest jock of the school and if you ever tell anybody this I'll kill you, but I know exactly what that girl feels like." That's something we need to pay attention to.

There was a poll recently published that asked teenagers if they found any meaning in their high school experience, if they were learning things that were relevant and useful to their lives. The number of kids who said they found absolutely no meaning in their high school experience has doubled since the late 1980s. Think about it. There are an awful lot of kids who feel forced to attend class. And they are forced to sit in their chairs for eight hours a day, 180 days a year with people they don't like, having to do things they don't like. Am I describing anyone's job? But the kids don't get paid for it, and they get yelled at when they don't do it well. We are failing our children. The outcomes are predictable. Kids have lost respect for the institution, and so respect for teachers diminishes. That makes your job so much harder because the students don't see why they should be doing this and those of you who really care-you burn out. Sometimes you have to leave the profession because it is exquisitely hard. You guys already know about this.

Why do I appear so passionately frustrated by all of this? Because I, all of us, know how to fix it very 
easily. Literature is an easy, affordable, multidimensional, cross-curricular way to both educate teens about the world and allow them to learn about themselves and their pretensions in a safe and productive way. Just give me five minutes with the president, that's all I need, five minutes.

Don Gallo, who is a known educator and one of my big heroes, has a great quote. He says "We are a

nation that teaches its children how to read in

The goal is to produce, at graduation, every single

child in America who can

read and read well, and

who will read broadly,

who will read for fun, who

will read for enlighten-

ment, for work, who will

read for safety, who will

read to get information in

emergency situations,

who will read for informa-

tion, who will read to

make intelligent political

deci-sions, and who will

read for cultural under-

standing. to read and to read well to be fully aware as a human. That's just my personal opinion.

Well, what about the canon, you ask?

Throw it overboard, and let it sink to the bottom of the sea. Not all of you are clapping. Give me a minute, all right? There are a lot of reasons why you should keep it, of course. First of all, money-your schools have invested all that money in all those darn books, and they're not going to take very kindly to the notion that they all need to be tossed to the bottom of the sea. They could also line cages at the animal shelter.

Then there is tradition. We have a tradition of eighty years of teaching these books at our high schools. And a lot of these books we teach in the canon are the foundation of our culture. I'm all about that. I personally believe a lot of the text that we use in the English literature should be taught as social studies and they can be excerpted. "The Scarlet Letter," which everybody knows I loathe, does have some important points to it, but that text is too dense. Most of the books in the canon were not written for teenagers. Very few adults pick up those books and read them for fun. They were written in different time periods for different audiences with different needs and desires.

Think about how much the curriculum in American high schools in math, science and history has changed since the 1940s. Pretty substantially, right? There used to be books that said someday we'll go to the moon. The English curriculum by comparison has not changed at all since 1940. A Steven King book will be thrown in for an alternative education class, but for the most part, the books are very much the same.

What I'm talking about here is not necessarily the $\mathrm{AP}$ and honor kids; they're going to do well no matter what challenges they're presented. I do think, however, that they want to read for fun sometimes, too, and we should allow them to do that. Let me give you two quick examples to help you really understand what this feels like to the average high school student. I want you to do this next week. Go to your local community college library and take out a book on chemical engineering. The librarian will be able to tell you where it is. I want you to take that book everywhere you go for a week. I want you to read it in the faculty room. I want you to go home, turn on MTV 
and read it. I want you to be e-mailing your friends while reading your chemical engineering text. I want you to get a group of your friends together, go to Starbucks, stand up in the middle of Starbucks and read out loud that chemical engineering text. That experience for you is going to help you know what it feels like for the average teen reader, or the struggling reader, who reads below grade level, to try to plow through the books in the canon. They'll have as much meaning, and it will feel about as good.

I think that any book you assign in an English curriculum should be the kind of book that you, as an adult, would be comfortable reading on a beach because our attention span as adults on a beach, you know chilling out and enjoying life, is what a teenager's attention span is in the classroom. So, let's think about where young readers are and address them where they are. We don't expect fourth-graders to act like eighth-graders. Why do we expect ninthgraders to act like they are thirty? It doesn't work that way. Their brains aren't finished developing.

I would like you to think about taking the expression reluctant reader out of use. Don't call them reluctant readers; they are not. They are readers faced with high barriers (presented by the canon) and very high standards. They have high barriers to successful reading; it's hard for them, and you know what? A lot of these kids are too smart to willingly endure boring books. They want to read something that has meaning, that's interesting, that speaks to their condition. My daughter, Merideth, didn't like to read; she had very low reading scores, about three grades below grade level. But, she got to the seventh grade, and they taught her about the Holocaust in social studies.

She came home and she said, "Mommy, did that happen?"

And I said, "Oh yeah; in fact, your grandfather was a soldier in that war."

And she said, "Do they have any books about it?"

Now, I've been waiting this kid's entire life to hear those words, and I said, "I think so." We now have in our house the largest collection of juvenile literature about the Holocaust of any household in America. The interest in that subject propelled my daughter beyond her own low reading skills, and she was very interested in reading about it. She became a great reader. She goes to college next year and intends to major in education.
Young adult literature is multicultural literature. We have accepted, pretty much every place in America, although I'm not sure about a few counties, the need for multicultural reading in the curriculum. And if you think about adolescence as its own unique culture: the language, music, artistic expression, you will realize that they deserve books that reflect their cultural experience and what is going on inside of them.

Now, I know I am preaching to the choir. If you guys took the time, the trouble and the money to show up at a state English teachers' convention on a

Saturday, you already understand an awful lot of this. There is one piece about which I want to sort of pump you up so when you go home you'll say, "We need to put this in the curriculum." We have Walter Dean Meyers and Gary Soto and all these authors that speak to the conditions of our readers so we can finally, in A lot of these kids are too smart to willingly endure boring books. They want to read something that has meaning, that's interesting, that speaks to their condition. generation. We haven't done that yet.

The last thing I want to tell you about is something that I hear from kids over and over and over again when they talk to me and when they write to me. They include kids marching their way toward the penitentiary, as well as kids on their way to MIT. The one common thread that unites them is that they love good teachers. They always tell me, "I hate school. It sucked, but there was this one teacher. . ." It could be a biology teacher, a gym teacher, anybody, but there's always this one teacher. I'm here to tell you, this is the honest to goodness truth, I would be dead today, I would have been dead at age sixteen if it hadn't been for a couple of teachers in my high school. I was teetering on the edge of disaster. I was ready to go from soft drugs into very hard and nasty drugs. I was hanging out with people who are all dead now. The reason that I'm not dead is that I had teachers, not that they would help me with my homework, not that they would give me good grades, but I had teachers that would look me in the eye and say, "Hi, how are you doing? I haven't seen you in a while. Welcome 
back. Now you have to serve detention, but I'll be there."

I knew that those teachers loved me and they were so strong and they were so wonderful and they were willing to risk their hearts on someone like me-the biggest loser on the planet, but they loved me even so. I hope you as teachers know that if you have the courage and the strength and the gift and the blessings to go forth and love those teenagers in your life, you will change the world. They need it, they want it, and they are so grateful! But they'll probably never,
I hope you as teachers know that if you have the courage and the strength and the gift and the blessings to go forth and love those teenagers in your

life, you will change the world. They need it, they

want it, and they are so grateful! But they'll probably never, ever tell you, so I'm here to tell you 